\title{
Society Perception Toward Flood Prevention in Sentosa Klang Park Selangor Malaysia
}

\author{
*Ceri Fitria ${ }^{1}$ and Faza Amalia ${ }^{2}$ \\ ${ }^{1}$ Graduate Student of Geography Education, Universitas Negeri Padang, Indonesia \\ e-mail: cerifitria08@gmail.com \\ ${ }^{2}$ Student of Geography, Malaya University, Malaysia \\ e-mail: indonesianvolcanologist@gmail.com
}

*Corresponding Author, Received: September 14, 2018, Revised: October 21, 2018, Accepted: December 05, 2018

\begin{abstract}
The purpose of this research was to analyze public perceptions of flood prevention, the effects of floods, and the factors that caused flooding in Sentosa Klang park Selangor Malaysia. This type of research is descriptive qualitative using literature review technique, observation, interview, and documentation studies in data collection. The types of data used are primary data and secondary data obtained from the Malaysian literature review. Primary data is collected by conducting an interview with informants and making an observation or open observation related to people's perception of flood prevention that occurred in Sentosa Klang park, Selangor Malaysia. Search via the internet is related to flood information, as well as a document that has been published by relevant agencies. The results of the research found by the authors indicate that the Malaysian Government has adopted a policy for flood prevention but has not gone well. Factors of flooding in Sentosa Klang park, Selangor Malaysia due to changes in land use, lack of water catchment area, small and clogged drainage channel, lack of public awareness of the surrounding environment, and lower topography. The impact that is often felt by the post-flood population is a skin disease, dengue fever, odour, and material losses.
\end{abstract}

Keywords: Society Perception, Flood prevention, Flood Factors, Danger of flooding, Flood Impacts.

\section{Introduction}

The environment is a resource in which environmental conditions change both quickly and slowly by various causes and their various effect (Hermon, 2010a; Hermon, 2012a). Changes to environmental components will affect other components (Hermon, 2015; Hermon, 2016). Population growth in an area will have a positive and negative effect on environmental components such as land changes, drainage, and loss of habitat for flora and fauna. Population growth requires food, shelter, clean water, which can be met by the environment (Hermon, 2017). Land use change will affect other components including water resources, and land (Coppola, 2007).

Changes in land use (land use) from plantation land to settlements, especially in recharge areas, have an impact on changes in surface water function, namely the occurrence of a reduction in base flow and groundwater infiltration (Hermon, 2001; Hermon and Khairani, 2008; Oktorie, 2017). On the other hand, an increase in surface runoff volume has caused a water imbalance. This has an impact on the deterioration of environmental quality due to a decrease in the quality and quantity of water due to the lack of water that seeps into the ground and an increase in surface flow during the rainy season causing flooding (Sudarto, 2009; Hermon, 2010b). 
Flooding is a form of natural phenomenon that occurs due to high rainfall intensity where there is excess water that is not accommodated by the network of breaking up an area. These conditions have an impact on the occurrence of inundation in the area which can harm the community (Harjadi et al., 2017; Hermon, 2010c; Hermon, 2012b). The increase in rainfall intensity dynamically and significantly that occurs, in general, is caused by an increase in the impact of global warming in the form of an increase in the earth's surface temperature caused by activities that occur on the surface (Hermon, 2012c). Hermon (2014); Hermon (2016a); Hermon (2016b) also stated that flooding is the most frequent and most harmful natural threat, both in terms of humanity and economics. Losses caused by flooding are often difficult to overcome by both the community and related institutions. Flooding as a natural disaster that can potentially damage and harm the lives of even human victims. While Baharuddin et al (2012a); Ching et al (2013); Hermon et al (2017); Hermon et al (2018a); Hermon et al (2018b) stated that flooding is a rather high flow of water that exceeds the cliffs of a river or creek sections. According to them again, flooding is an overflow of water that applies to a large area around which in normal conditions is not flooded. Flooding is a runoff that exceeds the normal water level so that it overflows from the riverbed which causes inundation on low land on the side of the river (Nurjanah et al., 2011; Kristian and Oktorie, 2018). In general, flooding is caused by high rainfall above normal, so that the water drainage system consisting of rivers and natural tributaries as well as drainage systems and artificial flood storage canals which are unable to accommodate the accumulation of rainwater so overflowing (Bakornas PB, 2007; Oktorie, 2018).

Flooding is a natural phenomenon where there is an excess of water that is not accommodated by a network of drains (drainage) in an area that causes harmful inundation. Losses caused by flooding are often difficult to overcome both by the community and related institutions. Flooding is caused by a variety of factors, namely rainfall catchment conditions, duration and intensity of rain, topographic conditions, and capacity of the drainage network (Syarief, 2010). Flooding in urban areas has different characteristics from flooding on land/nature. In conditions in nature, rainwater that drops to the ground will flow according to the contour of the existing land in a lower direction. For urban areas in general, falling rainwater will be channelled into artificial channels which drain water into the river. The contour of the land in urban areas is planned so that falling rainwater flows into artificial channels. There are times, the capacity of the channel is not sufficient to accommodate the rainwater that occurs, resulting in flooding (Suherlan, 2011). Floodplain is an area formed due to flood sedimentation. When floods occur, not only the water carried but also the lands that come from downstream of the river. Floodplains are usually formed in river meeting areas. As a result of this sedimentation event, the floodplain is a fertile area for agriculture, has shallow groundwater so it is suitable for settlements and urban areas. There are two factors that change why floods occur. First, changes in the environment in which there is climate change, geomorphological changes, geological changes and spatial changes. And second is the change from the community itself. Rain is a major factor causing flooding. Climate change causes the rain pattern to change where the current rain has a short but high intensity. As a result of this condition, the existing channels are no longer able to accommodate the amount of surface flow and soils are subject to rapid saturation. Changes in land use and automatic changes in land cover also occur. The land use there are settlements, fields, fields, fields etc. Whereas the land cover vegetation that grows above the earth's surface causes higher surface runoff. Surface flow occurs when rainfall has exceeded the rate of soil infiltration (Anonim, 2012). Malaysia is a developing country with a vision and mission to become a developed country by 2020 . The government has planned to develop the country through various major projects, for example, the construction of the Petronas Twin Tower or KLCC, which is one of the main pillars of Malaysian development and ability to compete with Asian countries others. But some things still cannot be overcome with the emergence of such developments, floods. In Malaysia, events that often haunt the population are floods that occur almost every year and succeed in destroying public property and private property (Messner \& Meyer, 2005). Malaysia is rich in water resources because annual rainfall is between $1500 \mathrm{~mm}$ to $3000 \mathrm{~mm}$ per year with an average of $2400 \mathrm{~mm}$ (Tuan Pah Rokiah 2015). Nagari Selangor is one of thirteen Nagari that formed Malaysia, the total population of Selangor is 4,613,000 people with an area of $7,956 \mathrm{~km} 2$. Nagari Selangor has a level of rainfall that reaches $2100 \mathrm{~mm} /$ year so that some regions in the Nagari Selangor often experience flooding. Sentosa Housing park is one of the many housing built by the developer in Selangor. This housing is located in Klang City, Malaysia's industrial centre and trade route because in the city of Klang there is Malaysia's main port. Taman Sentosa housing was once an oil palm plantation which was later converted and used as a residential area. 


\section{Method}

The type of this research used qualitative descriptive research by describing or describing in detail the perception of the society towards flood prevention in Sentosa Klang park Selangor Malaysia. Bogdan and Taylor in Moleong (2009); Hermon et al (2008) suggest that qualitative methods are studies that produce qualitative descriptive data in the form of written words from people and observable behaviour.Data collection techniques in the form of literature reviews, observations, interviews, and documentation studies. The types of data used are primary data and secondary data obtained from the Malaysian literature review. Primary data is collected by interviewing resource persons and conducting observations or open observations related to public perceptions of Flood countermeasures at Sentosa Klang park Selangor Malaysia, internet searches related to flood prevention information that often occurs in Malaysia, as well as documents that have been published by relevant agencies.

\section{Results and Discussion}

\section{Perception of the Sentosa society Klang Selangor About Flood Management by the Malaysian Government}

Based on the results of interviews conducted on 20 respondents living in Sentosa Klang park Selangor housing in Malaysia, they stated:

1. Flood Disaster in Sentosa Housing Klang Selangor has begun to be overcome by the Malaysian government by increasing the ditch or drainage found in residential areas and around the market, and the government tries to close the trench so that the waste does not enter into, but this development has not been implemented optimally. Seen in the field the milestones for trenching are still neatly arranged on the side of the road, according to residents, the milestone has been arranged for 1 year.

2. The Malaysian government has begun to demolish janitors to clear the blocked ditches/drainage. But the officer only cleans at the points that are problematic.

3. The government plans to build a Smart Tunnel, a tunnel built under the city with the aim of overcoming flooding in Malaysia. Then developed for various types of needs such as LRT (Light Transport Railway) tunnels, toll roads, to those used for hybrids (toll roads as well as for flood control. But this is still in the planning stage.

The Stormwater Management and Road Tunnel (SMART Tunnel), E38, are storm drainage and road structures in Kuala Lumpur, Malaysia, and major national projects in the country. Tunnel $9.7 \mathrm{~km}(6.0$ miles) is the longest rainwater drainage tunnel in Southeast Asia and the second longest in Asia. The main purpose of this tunnel is to solve the problem of flash floods in Kuala Lumpur and also to reduce congestion along Jalan Sungai Besi and Loke Yew flyovers in Pudu during peak hours. There are two components of this tunnel, stormwater tunnels and toll road tunnels. This is the longest multi-purpose tunnel in the world. After construction in Kuala Lumpur, it will be continued to the Selangor Malaysia area, www.wikipidia.com

4. Community participation in Flood Disasters does not exist, where people are still lacking in cleaning activities. activities are only carried out if there is an appeal from the head of the Local society.

Mr Pah Rokiah and Jamaluddin (2012); Hermon et al (2018c), society involvement is very important in overcoming problems in an area because people are the dominant agents who are able to change the landscape in an area for their lives. They also argue that the development and implementation of awareness among the community are important to optimize the achievement of the implementation of programs that are held for mutual benefit. Proposals from citizens are based on their experience in dealing with flooding. Considerations for their recommendations need to be made in the process of increasing the effectiveness of the Flood Disaster management system in Malaysia, especially in Serian, Sarawak. The efforts of the authorities through a flood management system will be in vain without the involvement of the population, especially those at risk. The presence of respondents' dissatisfaction in this study clearly shows that the Flood Disaster management system in Serian still has room for improvement.

5. Greening in the Sentosa park area of Klang is still lacking, this is evidenced by the few plants in the residential area. Whereas plants have a good influence on water governance (hydrology) so as to 
minimize the chance of rainwater entering the soil (infiltration and percolation), and maximizing the volume of rainwater flowing on the surface.

Seyhan (1995) who stated that land use is a tangible manifestation of the influence of human activity on some of the physical surface of the earth. Land use will affect the flood vulnerability of an area, land use will play a role in the amount of water runoff resulting from the rain that has exceeded the rate of infiltration. Areas that are overgrown with trees will find it very difficult to drain runoff water, this is due to the large capacity of water uptake by the trees and the slow runoff due to being held back by the roots and trunks of trees. Land that is heavily planted by vegetation will infiltrate rainwater and more time taken by runoff to get to the river so that the possibility of flooding is smaller than areas that are not planted by vegetation.

\section{Flooding Factor in Sentosa Klang Park Selangor}

Based on the results of interviews conducted on 20 respondents living in the Taman Sentosa Klang Selangor housing in Malaysia, the floods at Taman Sentosa Klang housing were:

1. Environmental Conditions The Sentosa Housing in Klang Selangor has become increasingly alarming, oil palm plantations and swamps which function as water catchment areas have changed their function to become quite dense housing locations without being offset by the construction of new ditches/drainages so that the number of catchment areas is lost.

According to Dr Ir. Suripin, M. Eng. (2004) drainage means to drain, drain, dispose, or divert water. In general, drainage is defined as a series of water structures that function to reduce and remove excess water from an area or land, so that the land can function optimally. From another perspective, drainage is one of the elements of public infrastructure needed by the urban community in order to lead a safe, comfortable, clean and healthy city life. The drainage infrastructure here serves to drain surface water to water bodies (surface and subsurface water sources) and or infiltration buildings. Besides that, it also functions as a controller of surface water needs with measures to repair muddy areas and puddles.

The drainage function in urban areas is a. Immerse surface water to maintain groundwater conservation (water conservation). b. Control the excess surface water that can be used for water supply and aquatic life. c. Dry parts of the city area from inundation so as not to cause interference or loss to the environment d. Flowing the surface water and the nearest receiving water. e. Protect urban infrastructure and facilities that have been built.

2. The management of waste management is still lacking and has not been done well, so it needs more intensive socialization and coaching. Garbage that is dumped carelessly has the potential to clog water flow in the drainage system in an area. Especially if you throw it in the drainage system or river area, it contributes to the increasingly severe floods that occur.

According to Akhmad Jufriadi et al (2012) disaster is an event that threatens and disrupts people's lives, caused by natural and human factors, resulting in the emergence of loss of life and property. So far, disaster management efforts have been carried out by the Government to reduce risks not yet optimal. As a result, in the event of a disaster, the community has not been able to handle it on its own. This fact is because the disaster-prone areas of society do not have the knowledge to deal with disaster management. So that the factors of disaster occurrence need to be known to take preventive action. In this case, the flood is caused by several factors, namely the rain factor, the factor of the destruction of the watershed retention, the river channel development planning error factors, the river silting factor and the regional mismanagement factor and infrastructure development (Maryono, 2005).

3. The topography of the Taman Sentosa Klang residential area is included in the lowland category so it is very vulnerable to flooding. According to respondents, when there is high-intensity rain in the Taman Sentosa Klang area, rainwater will enter the residents' housing, so this worries local residents.

Regional characteristics that influence the part of rainwater include topography, drainage system, land use, land cover. Whereas the parameters or benchmarks for flood hazard or hazard can be determined based on a) Area of inundation $\left(\mathrm{km}^{2}\right.$ or ha), depth or height of flood $(\mathrm{m})$, flow velocity $(\mathrm{m} / \mathrm{sec} \mathrm{or} \mathrm{km} / \mathrm{h})$, washable material (rocks, trees, other hard objects), level of water density or thickness of sludge (m, cm), length of 
time inundation (hours, days, months), frequency of occurrence (Anonim, 2007b, Koodoatie and Syarif, 2008).

4. Malaysia has a rainfall of 2,000-3,000 mm/year, this is classified as high-intensity rainfall. This factor also triggered floods in Sentosa Klang housing and was supported by a poor drainage system and flat topography. According to Noor Syamimi et al (2014), most flood events are due to heavy rain that occurs during continuous or prolonged periods which results in an increase in the quantity of water that is greater than normal or overflowing or both. Serian floods have brought various impacts on the local population. After residents who face the Flood Disaster, their opinions and suggestions in reducing the risks and impacts of flooding need to be considered.

Rainfall is the amount of rainwater that falls on an area in a certain time. In the calculation of flood, discharge requires rainfall intensity data. Rainfall intensity is the height of rainfall that occurs during a period of time where the water is concentrated. Rainfall intensity is denoted by me in units of $\mathrm{mm} / \mathrm{hour}$. Duration is the duration of a rain event, high rainfall intensity generally occurs in a short duration and covers a wide area. Rainfall needed for flood control design is the average rainfall in all regions concerned, areas that have high rainfall intensity, the area will be more affected by floods (Loebis, 1992).

\section{The Effect Flooding in Sentosa Klang Park Selangor}

Based on the results of interviews conducted on 20 respondents living in Sentosa Klang park Selangor housing in Malaysia, the effect of the floods in Sentosa Klang park housing was:

1. The impact that is often felt after a flood is that many people are affected by diseases such as skin diseases and dengue fever. This is caused by water that is stagnant and mixed with samba to become a breeding ground for germs, one of which is mosquito breeding.

2. Some traders claimed that when the flood occurred and that it entered the store resulted in a considerable loss, reaching 1,000 RM. Whereas residents experienced furniture losses because they were submerged by floods.

3. Another impact of flooding is to cause unpleasant odours because of the waste carried by water. And if the water carries this mud is very troubling to residents, because it is difficult to clean the house.

Lilik Indawati said that flooding had a positive and negative impact. the negative impact of floods is divided into three subs namely: a) primary impact; b) secondary impacts and; c) tertiary impact. Primarily, that is physical damage to everything that is flooded. Floods can damage various types of existing infrastructure, including bridges, buildings, underground sewer systems, highways and canals. Secondarily, the effects that occur as a result of primary impacts, such as:

a) Water supply, that is, many contaminated water sources, so that clean drinking water is scarce.

b) Causing outbreaks of disease, due to unhygienic environmental conditions, the spread of flood-borne diseases is increasingly rampant.

c) Agriculture and food supplies are declining. Floods that inundate agricultural land that is ready for harvest, resulting in farmers' crop failure. As a result of the scarcity of agricultural products.

d) Deadly other organisms in the ecosystem. Certain plant species that are unable to survive and will die because they cannot breathe, cannot photosynthesize (due to rot).

e) Paralyzing the rate of land transportation. Transportation lines are damaged, so it is difficult to send emergency assistance to people in need. Whereas in tertiary terms, namely damage caused by flooding that lasts for a long time or long term, the tertiary impacts include: Economic difficulties due to damage to settlements caused by floods; in the tourism sector, there has been a decline in interest among tourists, communities around the flood have lost their livelihoods, food scarcity has driven up prices, etc.

\section{Malaysian Government Policy in Overcoming Floods}

Based on the results of interviews conducted on 20 respondents living in Taman Sentosa Klang Selangor housing, Malaysia said the Malaysian government had carried out a policy in overcoming flooding problems, including: 
1. The Malaysian government has made a policy of giving fines to people who dispose of as much as 300 $\mathrm{RM}$, carelessly this has a positive impact since this policy is carried out the problem of waste in Malaysia has begun to decrease.

2. Law of Malaysia Deed 171 concerning local royal deed in 1976 section VIII sex 69 concerning pollution of a tributary that reads "Anyone who commits an offence makes any damage to a tributary, channel, public ditch or drainage inside Malaysia will be fined two thousand ringgit or be imprisoned for a period of one year, if they still repeat it again they will be fined five hundred ringgit every time they commit a violation ".

3. Malaysian Law Deed 172 concerning 1976 city and village design deed section I subsection 15 (2) concerning land use which reads "Land use as a place to process waste or waste that makes material changes in land use, even if the land contains an element that has been determined for a specific purpose, if the surface area or height of the soil increases materially.

4. Malaysian Law Deed 127 concerning natural quality deeds around 1974 section IV sexy 33 concerning littering which reads' Under the law on the disposal of hazardous substances caused by pollution or waste from factories and households that damage the environment. The Director-General stated that everyone must comply with the provisions of the law, but the effects of these wastes can lead to deterioration of the environment or environmental elements towards health, policies, or human safety or threaten the lives of animals, birds, wildlife, fish. The Director-General informs each of the lawmakers, asks them to stop the problem, release or place according to the method and within the time specified in the notification with a fine of fifty thousand ringgit or jail for five years ".

The definition of government policy or public policy in principle is made on the basis of broad policies. According to Werf in Achmad Ridzki (2015) what is meant by the policy is an effort to achieve certain goals with certain goals and in a certain order. While the government policy has a standard understanding, namely a decision that is made systematically by the government with specific intentions and objectives that concern the public interest.

The following Understanding of public policy by the following experts:

a. Thomas R. Dye: "Public Policy is whatever the government chooses to do or not to do". (Public policy is whatever the government's choice is to do something or not do something).

b. James E. Anderson: "Public Policies are those policies developed by governmental bodies and officials". (Public policy is policies developed by government agencies and officials).

c. David Easton: "Public policy is the authoritative allocation of values for the whole society." (Public policy is the allocation of values legitimately to all members of the community).

\section{Conclusion}

Flood prevention in the Sentosa Klang park Selangor housing has begun to be overcome by the Malaysian government by repairing ditches or drainage, but the work has not been maximized. Environmental Conditions The Sentosa park Housing in Klang Selangor has become increasingly alarming, oil palm plantations and swamps that function as water catchment areas have changed the function of being housing locations that are quite dense so that many catchment areas are lost. Management of waste management is still lacking and has not been done well, so it needs more intensive socialization and coaching. The post-flood impact at the Sentosa Housing in Klang Selangor is that many residents are affected by skin diseases/itching, dengue fever, unpleasant odours and material losses caused by dirty water mixed with waste and garbage. The Malaysian Government has made a policy of giving fines to people who dispose of as much as $300 \mathrm{RM}$, carelessly this has a positive impact since this policy is carried out the problem of waste in Malaysia has begun to decrease.

\section{References}

Anonim. 2007. Pedoman Penanggulangan Banjir. Bakornas PB. Jakarta.

Anonim, 2012. http://mastugino.blogspot.com/2012/11/peristiwa-alam-besertadampaknya.html (Diakses Tanggal 25 Juli 2018) 
Ariyanda, A.R. 2015. Persepsi Masyarakat Tentang Penanggulangan Banjir Oleh Pemerintah Kota Samarinda (Studi Banjir di Kelurahan Loa Bakung). Journal Sos FISIP UNMUL.

Badan Koordinasi Nasional Penanggulangan Bencana (BAKORNAS PB). 2007. Pengenalan Karakteristik Bencana dan Upaya Mitigasinya di Indonesia. Jakarta: Direktorat Mitigasi Lakhar BAKORNAS PB.

Baharuddin Yatim, Maimon Abdullah, Salmijah Surif. 2012. Banjir: Bencana alam. In: Baharudin Yatim et al. (eds) Banjir besar Johor, pp. 13-18. Penerbit Universiti Kebangsaan Malaysia, Selangor.

Ching YC, Baharudin Y, Mohd Ekhwan T, Lee YH, Maimon A, and Salmijah S. 2013. Impact of climate change on flood risk in the Muar River Basin of Malaysia. Disaster Advances 6, 11-17.

Coppola, Damon P. 2007. Introduction to International Disaster Management. Elsevier,Oxford.

Fadli, Muh Natsir. 2017. Analisis Permasalahan Banjir Wilayah Kelurahan Karunrung Kecamatan Rappocini Kota Makasar. Skripsi. Fakultas Sains dan Teknologi UIN Alauddin Makasar

Hermon, D. 2001. Studi Kontribusi Penggunaan Lahan dan Vegetasi Terhadap Karakteristik Epipedon. Tesis Magister. Program Pascasarjana Universitas Andalas Padang.

Hermon, D., Khairani., Daswirman., Karim, Sutarman., Dasrizal., and Triyatno. 2008. Metode dan Teknik Penelitian Geografi Tanah: Aplikasi Instrumen dan Acuan Penelitian Geografi Fisik. Yayasan Jihadul Khair Center.

Hermon, D. 2010a. Analisis Spasial Tingkat Bahaya Longsor Toposequent Marapi Bagian Barat Kab. Tanah Datar. Jurnal Geografi. Vol. 2.

Hermon, D. 2010b. Arahan Kebijakan Pengembangan Permukiman pada Kawasan Rawan Longsor di Kota Padang. Jurnal SKALA. Vol. 1.

Hermon, D. 2010c. Geografi Lingkungan: Perubahan Lingkungan Global. UNP Press.

Hermon, D. 2012a. Dinamika Cadangan Karbon Akibat Perubahan Tutupan Lahan Permukiman di Kota Padang Sumatera Barat. Forum Geografi: Indonesian Juornal of Spatial and Regional Analysis. Volume 26. Issue 1. p: 45-52. Uniiversitas Muhammadiyah Surakarta.

Hermon, D. 2012b. Mitigasi Bencana Hidrometeorlogi: Banjir, Longsor, Degradasi Lahan, Ekologi, Kekeringan, dan Puting Beliung. UNP Press. Padang.

Hermon, D. 2012c. Analisis Erodibilitas Tanah dengan Metode Bouyoucos untuk Arahan Pertanian Konservasi Ideal dalam Pembangunan Berkelanjutan. Jurnal Pelangi. Vol. 2 Issue. 2.

Hermon, D. 2014. Impacts of Land Cover Change on Climate Trend in Padang Indonesia. Indonesian Journal of Geography. Volume 46. Issue 2. p: 138-142. Fakultas Geografi Universitas Gajah Mada.

Hermon, D. 2015. Geografi Bencana Alam. Jakarta: PT RajaGrafindo Persada.

Hermon, D. 2016a. Mitigasi Perubahan Iklim. Rajawali Pers (Radjagrafindo).

Hermon, D. 2016b. Estimate of Changes in Carbon Stocks Based on Land Cover Changes in the Leuser Ecosystem Area (LEA) Indonesia. Forum Geografi. Volume 29. Issue 2. p: 188-196.

Hermon, D. 2017. Climate Change Mitigation. Rajawali Pers (Radjagrafindo).

Hermon, D., P. Iskarni., O. Olivia., and R. Wilis. 2017. The Model of Land Cover Change into Settlement Area and Tin Mining and its Affecting Factors in Belitung Island, Indonesia. Journal of Environment and Earth Science. Volume 7 No. 6. p: 32-39. IISTE.

Hermon, D., Ganefri., A. Putra and O. Oktorie. 2018a. The Model of Mangrove Land Cover Change for the Estimation of Blue Carbon Stock Change in Belitung Island-Indonesia. International Journal of Applied Environmental Sciences. Volume 13. Issue 2. p: 191-202. Research India Publication.

Hermon, D., Y. Suasti., Ernawati., Afdhal., and H. Edial. 2018b. Geografi: Geografi untuk SMU. Jurusan Geografi Universitas Negeri Padang.

Hermon, D., A. Putra and O. Oktorie. 2018c. Suitability Evaluation of Space Utilization Based on Environmental Sustainability at The Coastal Area of Bungus Bay in Padang City, Indonesia. International Journal of GEOMATE. Volume 14. Issue 41. p: 193-202. Geomate International Society. 
Hussain, Tun Pah Rokiah Syed. 2015. Perubahan Guna Tanah dan Taburan Hujan Luar Biasa di DaerahDaerah Pedalaman Negeri Kedah. Journal Universiti Utara Malaysia. Hlm 58-69

Indawati, Lilik. 2015. Analisis Tingkat Kerawanan Banjir dan Persepsi Masyarakat Terhadap Upaya Pengurangan Dampak Banjir di Kecamatan Baureno Kabupaten Bojonegoro. Tesis. Fakultas Keguruan dan Ilmu Pendidikan Universitas Sebelas Maret Surakarta

Jufriadi, Akhmad. 2012. Sosialisasi "Pengurangan Resiko Bencana” Di Kecamatan Tempursari Kabupaten Lumajang Sebagai Upaya Pendidikan Mitigasi Bencana. ERUDIO, Vol. 1, No. 1, Desember 2012. ISSN: 23029021.

Kristian, A and O. Oktorie. 2018. Study of Coastal Mangrove Conservation in the World. Sumatra Journal of Disaster, Geography and Geography Education. Volume 2. Issue 1. p: 49-52

Loeb is, J. 1992. Banjir Rencana Untuk Bangunan Air. Departemen Pekerjaan Umum.

Maryono, A. 2005. Menangani Banjir, Kekeringan, dan Lingkungan. Yogyakarta: Gajah Mada University Press.

Messner F, Meyer V. 2005. Flood damage, vulnerability and risk perception - Challenges for flood damage research. Discussion Papers. Available from:http:/www.ufz.eu/export/data/ 1/29306_Disk_Papiere_2005_13.pdf.

Moleong, J. Lexy. 2009. Metode Penelitian Kualitatif. Bandung: Remaja Rosda Karya

Noor Syamimi Ishak, Azharudin Mohamed Dali, Mohamad Rodzi Abdul Razak. 2014. Sejarah banjir besar di Semenanjung Malaysia, 1926-1971. Jurnal Perspektif 6, 54-67.

Nurjanah. 2011. Manajemen Bencana. Bandung: Alfabeta.

Oktorie, O. 2017. A Study of Landslide Areas Mitigation and Adaptation in Palupuah Subdistrict, Agam Regency, West Sumatra Province, Indonesia. Sumatra Journal of Disaster, Geography and Geography Education. Volume 1. Issue. 1. p: 43-49. Master Program of Geography Education.

Oktorie, O. 2018. Model Kebijakan Responsif Pemulihan Bencana Letusan Gunung Sinabung. Jurnal Kapita Selekta Geografi. Volume 1. Issue 1. p: 15-20

Seyhan. 1995. Dasar-dasar hidrologi. Universitas Gajah Mada.

Syarief, A. 2010. Rapid Built-up Cover Changes on Flood Innudation Areas in Padang City, [Tesis] Central Library Bogor Agricultural University

Sudarto. 2009. Analisis Pengaruh Perubahan Tata Guna Lahan Terhadap Peningkatan Jumlah Aliran Permukaan. Tesis. Program Studi Ilmu Lingkungan Universitas Sebelas Maret Surakarta

Suherlan. 2001. Zonasi Tingkat Kerentangan Banjir Kabupaten Bandung Mengunakan System Informasi Geografis. (skripsi). Bogor. 2011. Sistem Informasi Geografis Identifikasi Saluran Air dan Lokasi Sumber Air Bersih Kota Cimahi Berbasis. http:elib.unikom.ac. (Diakses pada tanggal 25 Juli 2018).

Suripin. 2004. Pelestarian Sumber Daya Tanah dan Air, Penerbit Andi, Yogyakarta

Suripin. 2004. Sistem Drainase Perkotaan yang Berkelanjutan. Yogyakarta: Andi

Tuan Pah Rokiah Syed Hussain, Jamaluddin Md Jahi. 2012. Analisa penglibatan masyarakat dalam sistem pengurusan banjir di Lembangan Kelantan. Prosiding Seminar Antarabangsa Ke 5 Ekologi, Habitat Manusia dan Perubahan Lingkungan di Alam Melayu, hlm. 821-831. 